\title{
Biogeochemical processes in the continental slope of Bay of Bengal: I. Bacterial solubilization of inorganic phosphate
}

\author{
Surajit Das*, P.S. Lyla \& S. Ajmal Khan \\ Centre of Advanced Study in Marine Biology, Annamalai University, Parangipettai- 608 502, Tamil Nadu, India. \\ *surajit@myself.com
}

Received 17-VIII-2005. C Corrected 26-VI-2006. Accepted 08-XII-2006.

\begin{abstract}
Microorganisms play a vital role in the biogeochemical cycles of various marine environments, but studies on occurrence and distribution of such bacteria in the marine environment from India are meager. We studied the phosphate solubilizing property of bacteria from the deep sea sediment of Bay of Bengal, India, to understand their role in phosphorous cycle (and thereby the benthic productivity of the deep sea environment). Sediment samples were obtained from 33 stations between $10^{\circ} 36^{\prime} \mathrm{N}-20^{\circ} 01^{\prime} \mathrm{N}$ and $79^{\circ} 59^{\prime} \mathrm{E}-87^{\circ} 30^{\prime} \mathrm{E}$ along 11 transects at 3 different depths i.e. ca. $200 \mathrm{~m}, 500 \mathrm{~m}, 1000 \mathrm{~m}$ in each transect. Total heterotrophic bacterial (THB) counts ranged from 0.42 to $37.38 \times 10^{4} \mathrm{CFU} \mathrm{g}^{-1}$ dry sediment weight. Of the isolates tested, $7.57 \%$ showed the phosphate solubilizing property. The phosphate solubilizing bacterial genera were Pseudomonas, Bacillus, Vibrio, Alcaligenes, Micrococcus, Corynebacterium and Flavobacterium. These strains are good solubilizers of phosphates which ultimately may play a major role in the biogeochemical cycle and the benthic productivity of the Exclusive Economic Zone (EEZ) of Bay of Bengal, because this enzyme is important for the slow, but steady regeneration of phosphate and organic carbon in the deep sea. Rev. Biol. Trop. 55 (1): 1-9. Epub 2007 March. 31.
\end{abstract}

Key words: phosphorous, biogeochemical cycle, microbial loop, THB, phosphate solubilizing bacteria, Bay of Bengal.

Microorganisms play a vital role in the biogeochemical cycles of various marine environments. The microorganisms mediate between the dissolved, particulate and gaseous states of chemical compounds, thereby regulating the distribution of organic and inorganic nutrients throughout the ocean. The microorganisms are efficient in this as they penetrate the water and sediment most intimately by their high number of individuals (Hoppe and Gocke 1993). Microorganisms also possess a variety of catabolic enzymes which allow them to decompose various dissolved and particulate substrates by extracellular enzymes (Meyer-Reil 1994). Dissolved nutrients found in the aquatic environment make life possible since aquatic organisms are to directly or indirectly obtain most of their required nutritional elements from their habitats.
Further, the availability of organic carbon and inorganic nutrients in water limits the biological productivity of the aquatic environment.

Of the essential elements involved in the biogeochemical cycle of the marine environment, phosphorous and nitrogen are most often considered as the potential limiting factors. Most of the phosphate and nitrogen incorporated into the aquatic plants, animals and sediments are usually generated by bacterial action. As a result of this, dissolved and dead organic matter unusable by other organisms is subjected to microbial decomposition. Hence, the 'microbial loop' is important for recycling of phosphate and nitrogen in the water and sediment (Azam et al. 1983).

In the marine environment various processes are responsible for recycling of phosphorous. 
Large quantities of the element phosphorous are immobilized in living organisms and locked up in the sediments as insoluble inorganic and organic phosphorous compounds. This form of phosphorous being held in the sediments for long time, remains excluded from recycling. The phosphate solubilizing bacteria (PSB) are capable of dissolving this insoluble inorganic phosphorous into soluble inorganic phosphorous through the organic acid they produce which bind calcium, iron and aluminium into organic mineral compounds, thereby liberating the precipitated phosphate like calcium and apatite. Thus, phosphorous cycle interacts with the carbon cycle (Thingstad and Rassoulzadegan 1995), which may be important for C-limited bacteria in the deep sea (Hoppe and Ullrich 1999).

Studies on occurrence and distribution of such bacteria in the marine environment from India are meager. Ayyakkannu and Chandramohan $(1970,1971)$ and Venkateswaran and Natarajan (1983) from Porto Novo coastal environment; Promod and Dhevendaran (1987) from Cochin backwater; Kannapiran (1997) from Gulf of Mannar; De Souza et al. (2000) around Indian peninsula and Seshadri et al. (2002) from Chennai, southeast coast of India reported the phosphate solubilizing bacteria. But none of the study was made from the deeper waters. In this backdrop, the present study was undertaken on phosphate solubilizing bacteria (PSB) to understand their role in the phosphorous cycle and thereof the benthic productivity in the continental slope environment.

\section{MATERIAL AND METHODS}

The sediment samples were collected from the continental slope of Bay of Bengal using Smith McIntyre Grab $\left(0.2 \mathrm{~m}^{2}\right.$ mouth area) during Cruise No. 225 of Fishery and Oceanography Research Vessel Sagar Sampada in 2004 from latitude $10^{\circ} 36^{\prime} \mathrm{N}$ to $20^{\circ} 01^{\prime} \mathrm{N}$ and longitude $79^{\circ} 59^{\prime} \mathrm{E}$ to $87^{\circ} 30^{\prime} \mathrm{E}$, covering 33 stations from 11 transects (Table 1). The physicochemical parameters of the water viz. salinity, dissolved oxygen and pressure were determined by the on-board Sea-Bird's 911 plus CTD unit. Besides, the sediment parameters- water content, $\mathrm{pH}$, temperature, total organic carbon (El Wakeel and Riley 1956), texture (Krumbein and Pettijohn 1938) and porosity (Danovaro et al. 1999) were also determined.

The sediment samples were analyzed immediately on board onto Zobell's Marine Agar 2216e medium plate (Peptone: $5.0 \mathrm{~g}$; Yeast extract: $1.0 \mathrm{~g}$; Ferric citrate: $0.1 \mathrm{~g} ; \mathrm{K}_{2} \mathrm{HPO}_{4}$ : $0.5 \mathrm{~g}$; pH: $7.5 \pm 0.3$; Agar: $15.0 \mathrm{~g}$; Sea water: $1000 \mathrm{ml}$ ) by spread plate method. The plates were then incubated on board at $27^{\circ} \mathrm{C}$ and after 3 days colony forming units were counted and expressed as $\mathrm{CFUg}^{-1}$ dry sediment weight. The representative colonies were picked up and further purified by successive restreaking. The strains were stored in Zobell's marine agar slants at $4^{\circ} \mathrm{C}$. The bacterial isolates were then screened for phosphate solubilizing activity. Macro colonies of the isolates were developed onto Zobell's Marine Agar 2216e supplemented with $\mathrm{CaHPO}_{4}(5 \mathrm{~g} / \mathrm{l})$ by inoculating $3 \mu \mathrm{l}$ of overnight nutrient broth culture and incubated for three days at room temperature. The Phosphate solubilization was expressed as negative and positive depending on the halo zone formation around the macro colonies. The cultures which showed halo zone formation around them were considered to be the phosphate solubilizers. The size of the clear zone around the colonies showing phosphate solubilization was measured. The results were expressed as solubilization efficiency as described by Seshadri et al. (2002).

$$
\mathrm{E}=\frac{\text { Solubilization diameter }}{\text { Growth diameter }} \times 100
$$

Standard bacteriological procedures were carried out to identify the isolates up to generic level following the scheme given by Baumann et al. (1972), Oliver (1982) and Holt et al. (1994).

Simple correlation coefficient was calculated between the physico-chemical parameters of the water and sediment with the total 
TABLE 1

Location, water depth, organic carbon and texture of sediments for the stations

\begin{tabular}{|c|c|c|c|c|c|c|}
\hline Transects & St. No & Latitude (N) & Longitude (E) & Depth (m) & $\begin{array}{c}\text { Total Organic } \\
\text { Carbon }(\mathrm{mg} / \mathrm{g})\end{array}$ & $\begin{array}{c}\text { Texture of the } \\
\text { sediment samples }\end{array}$ \\
\hline \multirow{3}{*}{ Karaikkal } & S48 & $10^{\circ} 34^{\prime} 96^{\prime \prime}$ & $80^{\circ} 26^{\prime} 70^{\prime \prime}$ & 248 & 2.5 & Sandy clay loam \\
\hline & S49 & $10^{\circ} 36^{\prime} 64^{\prime \prime}$ & $80^{\circ} 30^{\prime} 67^{\prime \prime}$ & 521 & 2.3 & Sandy clay loam \\
\hline & $\mathrm{S} 50$ & $10^{\circ} 36^{\prime} 16^{\prime \prime}$ & $80^{\circ} 36^{\prime} 23^{\prime \prime}$ & 950 & 4.5 & Clay \\
\hline \multirow{3}{*}{ Cuddalore } & S51 & $11^{\circ} 31^{\prime} 82^{\prime \prime}$ & $79^{\circ} 59^{\prime} 01^{\prime \prime}$ & 214 & 2.6 & Sandy clay \\
\hline & $\mathrm{S} 52$ & $11^{\circ} 31^{\prime} 44^{\prime \prime}$ & $80^{\circ} 02^{\prime} 16^{\prime \prime}$ & 512 & 4.5 & Clay \\
\hline & S53 & $11^{\circ} 32^{\prime} 03^{\prime \prime}$ & $80^{\circ} 07^{\prime} 55^{\prime \prime}$ & 912 & 3.9 & Silty clay \\
\hline \multirow{3}{*}{ Cheyyur } & S54 & $12^{\circ} 18^{\prime} 81^{\prime \prime}$ & $80^{\circ} 29^{\prime} 35^{\prime \prime}$ & 216 & 3.0 & Sandy loam \\
\hline & S55 & $12^{\circ} 21^{\prime} 68^{\prime \prime}$ & $80^{\circ} 33^{\prime} 49^{\prime \prime}$ & 490 & 3.5 & Silty clay \\
\hline & S56 & $12^{\circ} 21^{\prime} 34^{\prime \prime}$ & $80^{\circ} 36^{\prime} 10^{\prime \prime}$ & 937 & 4.0 & Silty clay \\
\hline \multirow{3}{*}{ Chennai } & S57 & $13^{\circ} 09^{\prime} 78^{\prime \prime}$ & $80^{\circ} 36^{\prime} 66^{\prime \prime}$ & 225 & 4.3 & Silty clay \\
\hline & S58 & $13^{\circ} 09^{\prime} 95^{\prime \prime}$ & $80^{\circ} 41^{\prime} 99^{\prime \prime}$ & 516 & 3.5 & Silty clay \\
\hline & S59 & $13^{\circ} 10^{\prime} 21^{\prime \prime}$ & $80^{\circ} 43^{\prime} 18^{\prime \prime}$ & 970 & 3.8 & Sandy clay \\
\hline \multirow{3}{*}{ Tammenapatanam } & S60 & $14^{\circ} 10^{\prime} 65^{\prime \prime}$ & $80^{\circ} 24^{\prime} 97^{\prime \prime}$ & 228 & 4.5 & Clay \\
\hline & S61 & $14^{\circ} 10^{\prime} 99^{\prime \prime}$ & $80^{\circ} 26^{\prime} 37^{\prime \prime}$ & 477 & 5.5 & Clay \\
\hline & S62 & $14^{\circ} 10^{\prime} 23^{\prime \prime}$ & $80^{\circ} 27^{\prime} 04^{\prime \prime}$ & 1000 & 4.9 & Silty clay \\
\hline \multirow{3}{*}{ Singarayakonda } & S63 & $15^{\circ} 15^{\prime} 19^{\prime \prime}$ & $80^{\circ} 31^{\prime} 68^{\prime \prime}$ & 240 & 4.6 & Clay \\
\hline & S64 & $15^{\circ} 15^{\prime} 32^{\prime \prime}$ & $80^{\circ} 33^{\prime} 47^{\prime \prime}$ & 507 & 4.8 & Clay \\
\hline & S65 & $15^{\circ} 16^{\prime} 33^{\prime \prime}$ & $80^{\circ} 35^{\prime} 82^{\prime \prime}$ & 960 & 5.5 & Clay \\
\hline \multirow{3}{*}{ Divipoint } & S66 & $16^{\circ} 00^{\prime} 09^{\prime \prime}$ & $81^{\circ} 29^{\prime} 57^{\prime \prime}$ & 223 & 4.9 & Clay \\
\hline & S67 & $16^{\circ} 04^{\prime} 70^{\prime \prime}$ & $81^{\circ} 49^{\prime} 67^{\prime \prime}$ & 502 & 5.5 & Clay \\
\hline & S68 & $16^{\circ} 00^{\prime} 67^{\prime \prime}$ & $82^{\circ} 03^{\prime} 29^{\prime \prime}$ & 917 & 4.9 & Silty clay \\
\hline \multirow{3}{*}{ Kakinada } & S69 & $17^{\circ} 00^{\prime} 16^{\prime \prime}$ & $83^{\circ} 01^{\prime} 86^{\prime \prime}$ & 220 & 5.5 & Clay \\
\hline & $\mathrm{S} 70$ & $17^{\circ} 00^{\prime} 07^{\prime}$ & $83^{\circ} 12^{\prime} 70^{\prime \prime}$ & 500 & 4.8 & Clay \\
\hline & S71 & $17^{\circ} 01^{\prime} 45^{\prime \prime}$ & $83^{\circ} 21^{\prime} 18^{\prime \prime}$ & 901 & 5.3 & Clay \\
\hline \multirow{3}{*}{ Bhemuli } & $\mathrm{S} 72$ & $18^{\circ} 01^{\prime} 49^{\prime \prime}$ & $84^{\circ} 15^{\prime} 62^{\prime \prime}$ & 222 & 4.7 & Clay \\
\hline & S73 & $18^{\circ} 01^{\prime} 93^{\prime \prime}$ & $84^{\circ} 16^{\prime} 26^{\prime \prime}$ & 550 & 5.3 & Clay \\
\hline & S74 & $18^{\circ} 01^{\prime} 13^{\prime \prime}$ & $84^{\circ} 20^{\prime} 28^{\prime \prime}$ & 850 & 5.0 & Clay \\
\hline \multirow{3}{*}{ Barua } & S75 & $19^{\circ} 03^{\prime} 37^{\prime \prime}$ & $85^{\circ} 25^{\prime} 81^{\prime \prime}$ & 260 & 4.8 & Clay \\
\hline & S76 & $19^{\circ} 06^{\prime} 37^{\prime \prime}$ & $85^{\circ} 32^{\prime} 55^{\prime \prime}$ & 500 & 4.8 & Clay \\
\hline & S77 & $19^{\circ} 05^{\prime} 63^{\prime \prime}$ & $85^{\circ} 39^{\prime} 03^{\prime \prime}$ & 994 & 4.0 & Clay \\
\hline \multirow{3}{*}{ Paradweep } & S81 & $20^{\circ} 05^{\prime} 29^{\prime \prime}$ & $87^{\circ} 11^{\prime} 14^{\prime \prime}$ & 273 & 5.2 & Clay \\
\hline & $\mathrm{S} 82$ & $20^{\circ} 04^{\prime} 32^{\prime \prime}$ & $87^{\circ} 12^{\prime} 19^{\prime \prime}$ & 503 & 4.8 & Clay \\
\hline & S83 & $20^{\circ} 01^{\prime} 04^{\prime \prime}$ & $87^{\circ} 30^{\prime} 95^{\prime \prime}$ & 958 & 4.3 & Silty clay \\
\hline
\end{tabular}


heterotrophic bacterial population and percentage of phosphate solubilizing bacteria.

\section{RESULTS}

In the present study, total heterotrophic bacterial (THB) counts ranged from 0.42 to $37.38 \times 10^{4} \mathrm{CFU} \mathrm{g}^{-1}$ dry sediment weight (Fig. 1). A total of 541 isolates obtained from all the stations were screened for the phosphate solubilizing property.

Salinity ranged from 34.73 to 35.02 psu. Higher salinity was observed at the depth of ca. $500 \mathrm{~m}$. Dissolved oxygen was in the range of
0.12 to $2.46 \mathrm{ml} / \mathrm{l}$ and was found to be higher at ca. $1000 \mathrm{~m}$ depth stations. While the temperature showed a regular trend of decreasing from ca. $200 \mathrm{~m}$ to ca. $1000 \mathrm{~m}$ stations, the pressure increased. Water content and $\mathrm{pH}$ of the sediment were in the range of $44.73-68.54 \%$ and 6.6-7.0 respectively. Total organic carbon varied in relation to the texture of the sediment and was in the range of 2.3-5.5 mg/g dry weight of sediment (Table 1). The textural characteristics are presented in Table 1 and the sediments were mostly clayey type.

Among all the bacterial isolates tested, only 41 isolates $(7.57 \%)$ showed the phosphate solubilizing property (Fig. 2) and the diameter

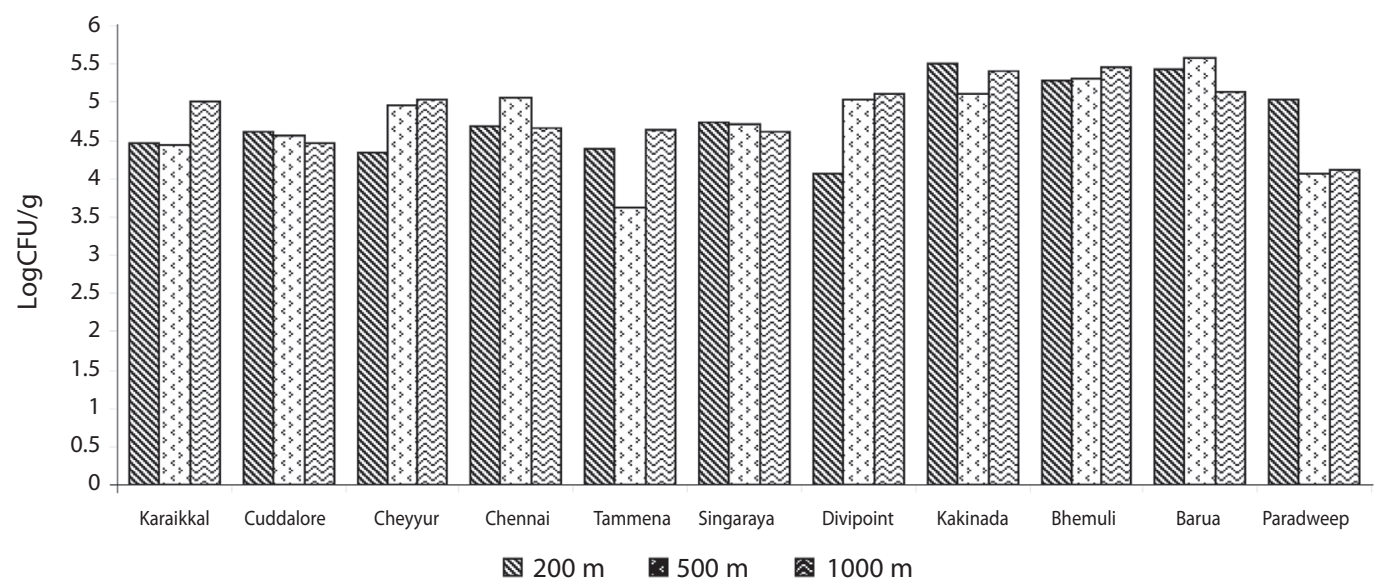

Fig. 1. Bacterial population in different stations located along various transects of Bay of Bengal.

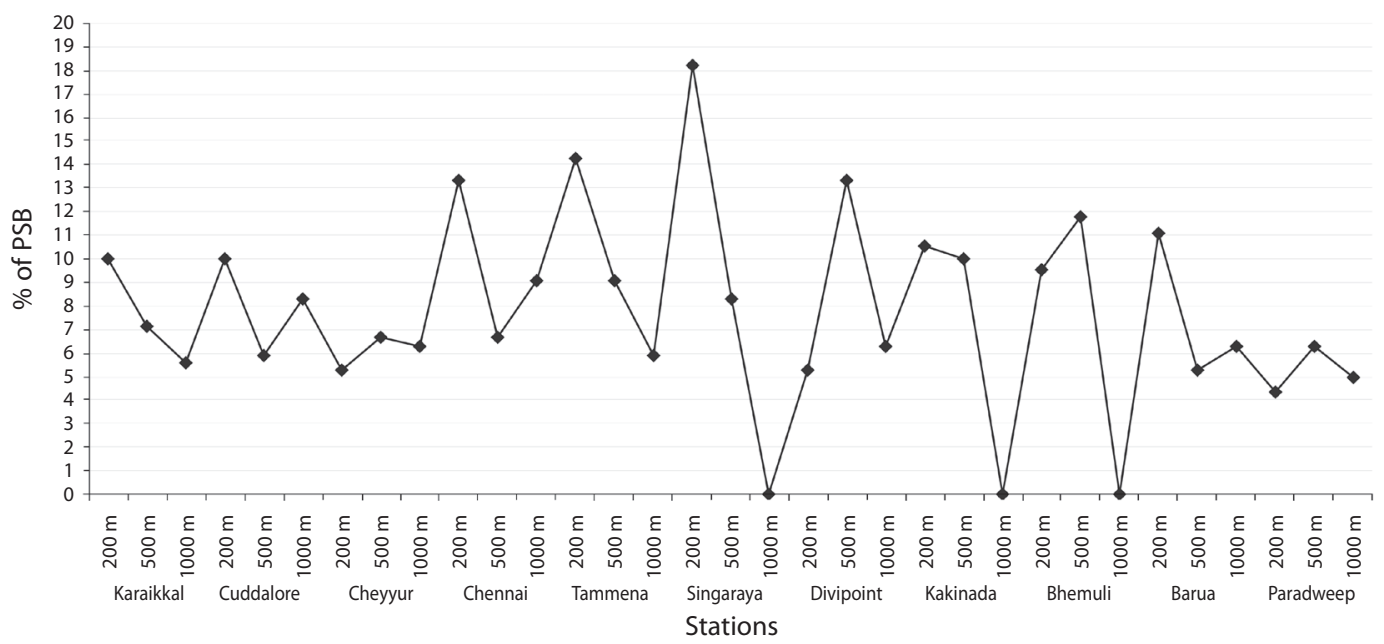

Fig. 2. Percentage contribution of phosphate solubilizing bacteria (PSB) in different stations. 
of the halo zone varied from $0.5 \mathrm{~cm}$ to $2.4 \mathrm{~cm}$ (Table 2). Phosphate solubilization index of bacterial isolates showing halo zone is given in Table 2, which ranged from 113.63 to 184.61 . The number of isolates and the solubilization index varied from station to station depending on the depth. The correlation coefficient values of the different physico-chemical parameters with the total heterotrophic bacterial population and the percentage of phosphate solubilizing bacteria are also given in Table 3.

Totally 7 genera, namely Pseudomonas, Bacillus, Vibrio, Alcaligenes, Micrococcus, Corynebacterium and Flavobacterium were observed as phosphate solubilizing bacteria and the percentage contribution of these genera in PSB are presented in Table 4.

\section{DISCUSSION}

\section{PSB and physicochemical parameters}

The higher solubilization index was noticed in the bacterial strains isolated from ca. $200 \mathrm{~m}$ depth whereas lower solubilization index was found in the strains isolated from ca. 1000 $m$ depth. De Souza et al. (2000) reported the percentage occurrence of phosphate solubilizing bacteria from different niches viz. beaches $(8.1 \%)$, Islands $(16.7 \%)$, coasts $(15.6 \%)$ and offshore $(8.7 \%)$ and it was found that phosphate solubilizing bacterial population is higher in coastal areas than offshore areas. It is probably that the offshore organisms are poor solubilizers of inorganic phosphate because these organisms are hampered by an insufficient supply of easily degradable organic compounds (Hoppe and Ullrich 1999) and low uptake of carbon (De Souza et al. 2000). Hence, the lower percentage occurrence of phosphate solubilizing bacteria observed in the present study may be due to the location of the stations in the deeper waters. But, in terms of phosphate solubilization efficiency, the isolates showed a good result. The solubilization index in the present study ranged from 113.63 to 184.61 with an average of 143.04 , whereas, from the coastal and offshore waters of India, the index varied from 105.56 to 205.86 with an average of 141.73 (Seshadri et al. 2002).

Moreover, the optimum temperature for this enzymatic activity was reported to be $27 \pm 2^{\circ} \mathrm{C}$ (De Souza et al. 2000). That is why the experiment was done at $27^{\circ} \mathrm{C}$, eventhough the sediment temperature in the sampling stations varied from $8^{\circ} \mathrm{C}$ to $17^{\circ} \mathrm{C}$ and tended to decrease from ca. $200 \mathrm{~m}$ to ca. $1000 \mathrm{~m}$ depth stations. At the optimum temperature it was believed to found higher solubilization index of PSB which might have lower solubilization property in their native temperature, taking into consideration of the fact that the isolates which had the phosphate solubilization property at lower temperature would show better result in the optimum temperature to ease the enumeration of PSB, and the isolates which showed no activity at the optimum temperature would not be having phosphate solubilization property in their inhabitant temperature also. Hence, it is believed that the influence of the inhabitant sediment parameters render the bacterial isolates to be phosphate solubilizers. Therefore, the lower solubilization index of the bacterial strains isolated from ca. $1000 \mathrm{~m}$ depth stations with compare to ca. $200 \mathrm{~m}$ and ca. $500 \mathrm{~m}$ depth stations may be attributed to the sediment temperature which is again supported by the correlation coefficient values (Table 3 ).

A significant positive correlation $(\mathrm{P}<0.01)$ was observed with the percentage of the phosphate solubilizers and the sediment temperature and a significant negative correlation was observed with the station depth and $(\mathrm{P}<0.01)$ the bottom water pressure $(\mathrm{P}<0.02)$ (Table 3 ). Although, significant positive correlation was observed with the total heterotrophic bacteria and the total organic carbon $(\mathrm{P}<0.05)$, clay fraction $(\mathrm{P}<0.01)$, porosity $(\mathrm{P}<0.05)$ and water content $(\mathrm{P}<0.05)$ of the sediment, the $\mathrm{PSB} \%$ showed no significance with these parameters. Benny and Kurup (1991) also reported that the extracellular enzyme (L-asparaginase) producing bacteria decreased with the increase of organic carbon in the estuarine sediment, but in contrast, Ayyakkannu and Chandramohan 
TABLE 2

Phosphate solubilizing bacterial distribution at different depths in Bay of Bengal

\begin{tabular}{|c|c|c|c|c|c|}
\hline Isolate Nos. & Genera & Station Depth & Area & $\begin{array}{l}\text { Diameter of } \\
\text { zone (mm) }\end{array}$ & $\begin{array}{c}\text { Solubilization } \\
\text { index }\end{array}$ \\
\hline SB 225.005 & Vibrio & $214 \mathrm{~m}\left(11^{\circ} 31 \mathrm{~N}-79^{\circ} 59 \mathrm{E}\right)$ & Off Cuddalore & 1.8 & 128.57 \\
\hline B 225.016 & Pseudomonas & $214 \mathrm{~m}\left(11^{\circ} 31 \mathrm{~N}-79^{\circ} 59 \mathrm{E}\right)$ & Off Cuddalore & 2.5 & 125.00 \\
\hline SB 225.027 & Bacillus & $248 \mathrm{~m}\left(10^{\circ} 34 \mathrm{~N}-80^{\circ} 26 \mathrm{E}\right)$ & Off Karaikkal & 1.7 & 170.00 \\
\hline SB 225.036 & Micrococcus & $248 \mathrm{~m}\left(10^{\circ} 34 \mathrm{~N}-80^{\circ} 26 \mathrm{E}\right)$ & Off Karaikkal & 2.1 & 123.52 \\
\hline SB 225.053 & Vibrio & $521 \mathrm{~m}\left(10^{\circ} 36 \mathrm{~N}-80^{\circ} 30 \mathrm{E}\right)$ & Off Karaikkal & 1.5 & 115.38 \\
\hline B 225.070 & Alcaligenes & $512 \mathrm{~m}\left(11^{\circ} 31 \mathrm{~N}-80^{\circ} 02 \mathrm{E}\right)$ & Off Cuddalore & 2.3 & 119.52 \\
\hline SB 225.080 & Pseudomonas & $912 \mathrm{~m}\left(11^{\circ} 32 \mathrm{~N}-80^{\circ} 07 \mathrm{E}\right)$ & Off Cuddalore & 1.5 & 115.63 \\
\hline B 225.085 & Corynebacterium & $216 \mathrm{~m}\left(12^{\circ} 18 \mathrm{~N}-80^{\circ} 29 \mathrm{E}\right)$ & Off Cheyyur & 1.1 & 137.50 \\
\hline SB 225.108 & Pseudomonas & $490 \mathrm{~m}\left(12^{\circ} 21 \mathrm{~N}-80^{\circ} 33 \mathrm{E}\right)$ & Off Cheyyur & 0.5 & 119.04 \\
\hline SB 225.125 & Alcaligenes & $937 \mathrm{~m}\left(12^{\circ} 21 \mathrm{~N}-80^{\circ} 36 \mathrm{E}\right)$ & Off Cheyyur & 1.1 & 114.58 \\
\hline SB 225.143 & Flavobacterium & $1000 \mathrm{~m}\left(14^{\circ} 10 \mathrm{~N}-80^{\circ} 27 \mathrm{E}\right)$ & Off Tammenapatanam & 1.5 & 115.38 \\
\hline B 225.156 & Vibrio & $225 \mathrm{~m}\left(13^{\circ} 09 \mathrm{~N}-80^{\circ} 36 \mathrm{E}\right)$ & Off Chennai & 0.8 & 160.00 \\
\hline B 225.160 & Bacillus & $225 \mathrm{~m}\left(13^{\circ} 09 \mathrm{~N}-80^{\circ} 36 \mathrm{E}\right)$ & Off Chennai & 1.8 & 150.00 \\
\hline B 225.172 & Pseudomonas & $516 \mathrm{~m}\left(13^{\circ} 09 \mathrm{~N}-80^{\circ} 41 \mathrm{E}\right)$ & Off Chennai & 2.0 & 125.00 \\
\hline B 225.190 & Alcaligenes & $228 \mathrm{~m}\left(14^{\circ} 10 \mathrm{~N}-80^{\circ} 24 \mathrm{E}\right)$ & Off Tammenapatanam & 1.3 & 173.33 \\
\hline SB 225.193 & Pseudomonas & $228 \mathrm{~m}\left(14^{\circ} 10 \mathrm{~N}-80^{\circ} 24 \mathrm{E}\right)$ & Off Tammenapatanam & 2.1 & 140.00 \\
\hline В 225.198 & Pseudomonas & $937 \mathrm{~m}\left(12^{\circ} 21 \mathrm{~N}-80^{\circ} 36 \mathrm{E}\right)$ & Off Chennai & 0.5 & 113.63 \\
\hline B 225.211 & Vibrio & $477 \mathrm{~m}\left(14^{\circ} 10 \mathrm{~N}-80^{\circ} 26 \mathrm{E}\right)$ & Off Tammenapatanam & 0.8 & 133.33 \\
\hline B 225.220 & Pseudomonas & $273 \mathrm{~m}\left(20^{\circ} 05 \mathrm{~N}-87^{\circ} 11 \mathrm{E}\right)$ & Off Paradweep & 0.9 & 180.00 \\
\hline B 225.246 & Micrococcus & $503 \mathrm{~m}\left(20^{\circ} 04 \mathrm{~N}-87^{\circ} 12 \mathrm{E}\right)$ & Off Paradweep & 1.6 & 118.51 \\
\hline B 225.267 & Vibrio & $958 \mathrm{~m}\left(20^{\circ} 01 \mathrm{~N}-87^{\circ} 30 \mathrm{E}\right)$ & Off Paradweep & 1.9 & 135.71 \\
\hline B 225.279 & Micrococcus & $500 \mathrm{~m}\left(19^{\circ} 06 \mathrm{~N}-85^{\circ} 32 \mathrm{E}\right)$ & Off Barua & 2.1 & 123.52 \\
\hline B 225.297 & Vibrio & $260 \mathrm{~m}\left(19^{\circ} 03 \mathrm{~N}-85^{\circ} 25 \mathrm{E}\right)$ & Off Barua & 2.5 & 156.26 \\
\hline B 225.304 & Bacillus & $260 \mathrm{~m}\left(19^{\circ} 03 \mathrm{~N}-85^{\circ} 25 \mathrm{E}\right)$ & Off Barua & 0.9 & 180.00 \\
\hline B 225.315 & Pseudomonas & $994 \mathrm{~m}\left(19^{\circ} 05 \mathrm{~N}-85^{\circ} 39 \mathrm{E}\right)$ & Off Barua & 1.5 & 115.38 \\
\hline B 225.334 & Micrococcus & $550 \mathrm{~m}\left(18^{\circ} 01 \mathrm{~N}-84^{\circ} 16 \mathrm{E}\right)$ & Off Bhemuli & 2.2 & 169.23 \\
\hline B 225.339 & Bacillus & $550 \mathrm{~m}\left(18^{\circ} 01 \mathrm{~N}-84^{\circ} 16 \mathrm{E}\right)$ & Off Bhemuli & 1.3 & 162.50 \\
\hline B 225.348 & Pseudomonas & $222 \mathrm{~m}\left(18^{\circ} 01 \mathrm{~N}-84^{\circ} 15 \mathrm{E}\right)$ & Off Bhemuli & 1.8 & 180.00 \\
\hline B 225.362 & Bacillus & $222 \mathrm{~m}\left(18^{\circ} 01 \mathrm{~N}-84^{\circ} 15 \mathrm{E}\right)$ & Off Bhemuli & 2.3 & 153.33 \\
\hline B 225.384 & Alcaligenes & $500 \mathrm{~m}\left(17^{\circ} 00 \mathrm{~N}-83^{\circ} 12 \mathrm{E}\right)$ & Off Kakinada & 1.9 & 146.15 \\
\hline B 225.394 & Corynebacterium & $500 \mathrm{~m}\left(17^{\circ} 00 \mathrm{~N}-83^{\circ} 12 \mathrm{E}\right)$ & Off Kakinada & 2.1 & 127.27 \\
\hline B 225.398 & Micrococcus & $220 \mathrm{~m}\left(17^{\circ} 00 \mathrm{~N}-83^{\circ} 01 \mathrm{E}\right)$ & Off Kakinada & 1.3 & 144.44 \\
\hline B 225.403 & Corynebacterium & $220 \mathrm{~m}\left(17^{\circ} 00 \mathrm{~N}-83^{\circ} 01 \mathrm{E}\right)$ & Off Kakinada & 0.7 & 175.00 \\
\hline В 225.434 & Bacillus & $223 \mathrm{~m}\left(16^{\circ} 00 \mathrm{~N}-81^{\circ} 29 \mathrm{E}\right)$ & Off Divipoint & 2.4 & 184.61 \\
\hline B 225.458 & Corynebacterium & $502 \mathrm{~m}\left(16^{\circ} 04 \mathrm{~N}-81^{\circ} 49 \mathrm{E}\right)$ & Off Divipoint & 1.12 & 140.00 \\
\hline B 225.465 & Bacillus & $520 \mathrm{~m}\left(16^{\circ} 04 \mathrm{~N}-81^{\circ} 49 \mathrm{E}\right)$ & Off Divipoint & 2.0 & 153.84 \\
\hline B 225.468 & Bacillus & $917 \mathrm{~m}\left(16^{\circ} 01 \mathrm{~N}-82^{\circ} 03 \mathrm{E}\right)$ & Off Divipoint & 1.2 & 150.00 \\
\hline B 225.485 & Flavobacterium & $240 \mathrm{~m}\left(15^{\circ} 15 \mathrm{~N}-80^{\circ} 31 \mathrm{E}\right)$ & Off Singarayakonda & 2.1 & 161.53 \\
\hline В 225.487 & Bacillus & $240 \mathrm{~m}\left(15^{\circ} 15 \mathrm{~N}-80^{\circ} 31 \mathrm{E}\right)$ & Off Singarayakonda & 1.2 & 171.42 \\
\hline 3 225.494 & Pseudomonas & $507 \mathrm{~m}\left(15^{\circ} 15 \mathrm{~N}-80^{\circ} 33 \mathrm{E}\right)$ & Off Singarayakonda & 0.7 & 140.00 \\
\hline 225.531 & Alcaligenes & $950 \mathrm{~m}\left(10^{\circ} 36 \mathrm{~N}-80^{\circ} 36 \mathrm{E}\right)$ & Off Karaikkal & 1.4 & 116.66 \\
\hline
\end{tabular}


$\sum_{m}^{\infty}$

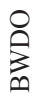

$-\stackrel{7}{0}$

$\sum_{n}^{\infty}$

$-\begin{array}{ll}n & n \\ 0 & 0 \\ 0 & 0\end{array}$

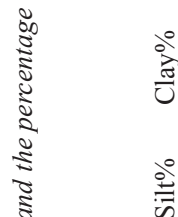

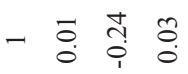

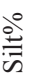

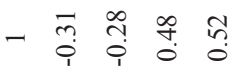

赵

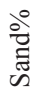

- 莳

?:

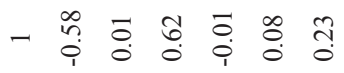

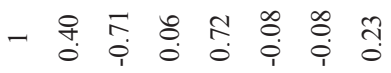

$m$ 돈ำ

$\stackrel{\circlearrowright}{\circ}$

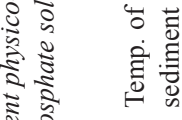

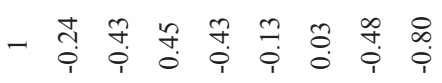

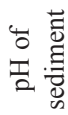

- -

离

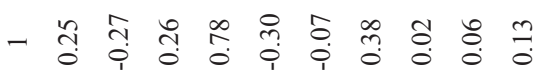

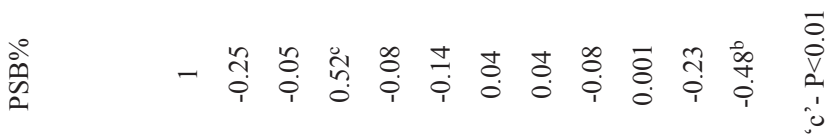

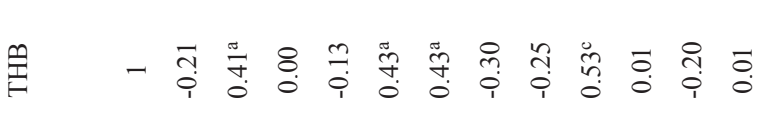

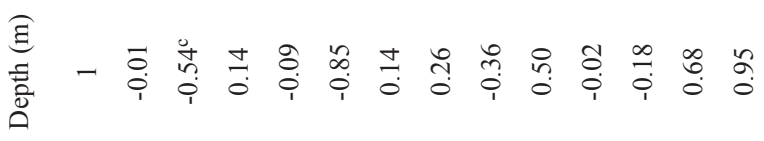

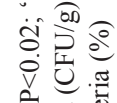

方

i :

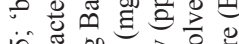

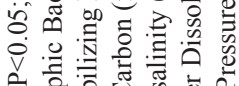

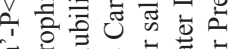

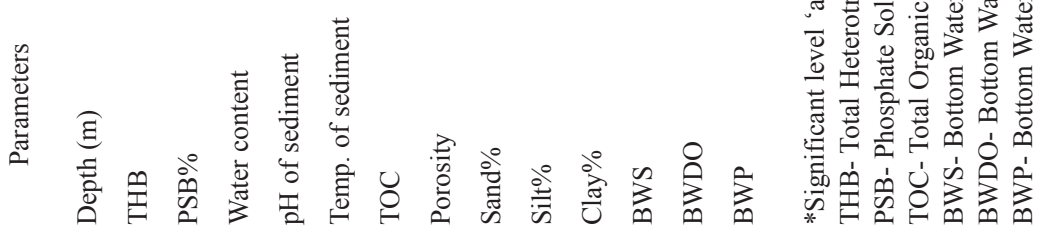


TABLE 4

Percentage contribution by different genera of phosphate solubilizing bacteria

\begin{tabular}{lcc}
\multicolumn{1}{c}{ Genera } & Total number & \% contribution \\
Pseudomonas & 10 & 24.39 \\
Bacillus & 9 & 21.95 \\
Vibrio & 6 & 14.63 \\
Alcaligenes & 5 & 12.2 \\
Micrococcus & 5 & 12.2 \\
Corynebacterium & 4 & 9.76 \\
Flavobacterium & 2 & 4.87
\end{tabular}

(1971) observed a positive correlation of the above with the organic carbon and the clay fraction of the sediment. Phosphatase activities in deeper waters have been measured even less than other hydrolytic activities which are due to the fact that phosphate is generally not the growth limiting factor in the euphotic zone of the sea (Rivkin and Anderson 1997).

\section{Generic composition of PSB}

Totally 7 genera, namely Alcaligenes, Pseudomonas, Bacillus, Corynebacterium, Micrococcus, Flavobacterium and Vibrio were observed as phosphate solubilizing bacteria from different stations, among which Pseudomonas contributed more $(24.39 \%)$ followed by Bacillus (21.95\%) and Vibrio (14.63\%). Alcaligenes and Micrococcus contributed equally (12.2\%), while Corynebacterium and Flavobacterium contributed $9.76 \%$ and $4.87 \%$ respectively (Table 4 ). Pseudomonas was found to be the predominant group which was also reported from the Indian west coast by Promod and Dhevendaran (1987) and De Souza et al. (2000) and from east coast of India by Venkateswaran and Natarajan (1983) and Seshadri et al. (2002). Promod and Dhevendaran (1987) and De Souza et al. (2000) reported Bacillus as the dominant group in the inshore areas and encountered Moraxella and Klebsiella respectively, which were absent in the present study. Whereas, Venkateswaran and Natarajan (1983) and Seshadri et al. (2002) found Pseudomonas and Bacillus as the most efficient phosphate solubilizing genera which are chiefly responsible for the mineralization of inorganic phosphorous compounds.

Extracellular phosphatase from phosphate solubilizing bacteria is a key enzyme in the marine environment which plays a prominent role in the recycling of organic $\mathrm{P}$ and in the avoidance of $\mathrm{P}$ limitation in the sea (Hoppe 2003). Thus, phosphate availability in sediment is greatly enhanced through microbial production of metabolites leading to lowering of $\mathrm{pH}$ and release of phosphate from organic and inorganic complexes. The distributions of the phosphate solubilizing bacteria in the continental slope sediment of Bay of Bengal emphasize the benthic productivity of that area in terms of nutrients and biogeochemical cycle.

The phosphate solubilizing bacteria have been reported earlier from the different niches but this study gives additional information on the phosphate solubilizing properties of bacteria isolated from the continental slope sediment of Bay of Bengal. It is evident from the present investigation that the bacterial strains isolated from the deep sea are good solubilizers of phosphates which ultimately may play a major role in the biogeochemical cycle and the benthic productivity of the Exclusive Economic Zone (EEZ) of Bay of Bengal, because this enzyme is important for the slow, but steady regeneration of phosphate and organic carbon in the deep sea.

\section{ACKNOWLEDGMENTS}

The authors are thankful to the Director, Centre of Advanced Study in Marine Biology for the encouragement, the authorities of Annamalai University for the facilities and the Centre for Marine Living Resources and Ecology, Ministry of Ocean Development, Government of India, Kochi for the financial support. 


\section{RESUMEN}

Estudiamos la capacidad que tienen las bacterias de sedimentos profundos en la Bahía de Bengala, India, de disolver los fosfatos que juegan un papel clave en los ciclos biogeoquímicos del mar. Recolectamos muestras en 33 estaciones ubicadas entre $10^{\circ} 36^{\prime} \mathrm{N}-20^{\circ} 01^{\prime} \mathrm{N}$ y $79^{\circ} 59^{\prime} \mathrm{E}-87^{\circ} 30^{\prime} \mathrm{E}$ en once transectos y tres profundidades, i.e. ca. $200 \mathrm{~m}, 500 \mathrm{~m}, 1000 \mathrm{~m}$. Los conteos totales de bacterias heterotróficas fueron de 0.42 a $37.38 \times 10^{4} \mathrm{CFU}$ $\mathrm{g}^{-1}$ (peso seco) de sedimento. De las cepas evaluadas, un $7.57 \%$ disuelven fosfato. Los géneros con esta características fueron Pseudomonas, Bacillus, Vibrio, Alcaligenes, Micrococcus, Corynebacterium y Flavobacterium.

Palabras clave: fósforo, ciclo biogeoquímico, ciclo microbiano, bacterias que disuelven fosfato, Bahía de Bengala.

\section{REFERENCES}

Ayyakkannu, K. \& D. Chandramohan. 1970. On the occurrence and distribution of phosphobacteria in the marine environment of Porto Novo. Curr. Sci. 39: 398-399.

Ayyakkannu, K. and D. Chandramohan. 1971. Occurrence and distribution of phosphate solubilizing bacteria and phosphatase in marine sediments at Porto Novo. Mar. Biol. 11: 201-205.

Azam F., T. Fenchel, J.G. Field, J.S. Gray, L.A. MeyerReil \& F. Thingstad. 1983. The ecological role of water-column microbes in the sea. Mar. Ecol. Prog. Ser. 10: 257-263.

Baumann L., P. Baumann, M. Mandel \& R.D. Allen. 1972. Taxonomy of aerobic marine eubacteria. J. Bacteriol. 10: 402-429.

Benny P.J. \& G. Muraleedhara Kurup. 1991. L-asparaginase activity in bacteria from estuarine sediments and mollusc. Indian J. Mar. Sci. 20: 36-39.

Danovaro R., D. Marrale, N. Della Croce, P. Parodi. \& M. Fabiano. 1999. Biochemical composition of sedimentary organic matter and bacterial distribution of in the Aegean Sea: trophic state and pelagic-benthic coupling. J. Sea. Res. 142: 1-13.

De Souza M.J.B.D., S. Nair \& D. Chandramohan. 2000. Phosphate solubilizing bacteria around Indian peninsula. Indian J. Mar. Sci. 29: 48-51.

El Wakeel S.K. \& J.P. Riley. 1956. The determination of organic carbon in marine muds. J. du. conseil permanent Intl. Poul. Exploration de la mer. 22: 180- 183.
Holt J.G., N.R. Krieg, P.H.A. Sneath, J.T. Stanley \& S. T. Williams. 1994. Bergey's manual of determinative bacteriology. $9^{\text {th }}$ Edition. Williams and Wilkins, Baltimore, Maryland, USA. 787 p.

Hoppe H.G. 2003. Phosphatase activity in the sea. Hydrobiologia 493: 187-200.

Hoppe H.G. \& K. Gocke. 1993. The influence of global climate and hydrography on microbial activity in the ocean, results of a N-S Atlantic transect. Proc. Inter. Symp. Environ. Microbiol., Korea, p. 93-110.

Hoppe H.G. \& S. Ullrich. 1999. Profiles of ectoenzymes in the Indian Ocean: phenomena of phosphatase activity in the mesopelagic zone. Aquat. Microb. Ecol. 19: 139- 148 .

Kannapiran E. 1997. Heterotrophic, phosphatase producing and phosphate solubilizing bacteria of the coral reef environment of the Gulf of Mannar Biosphere Reserve (Southeast coast of India): An Inventory. Ph.D Thesis, Annamalai University, India. 103 p.

Krumbein W.C. \& F.J. Pettijohn. 1938. Manual of sedimentary petrography. Applenton Century- Crofts, New York. 549 p.

Meyer-Reil L.A. 1994. Microbial life in sedimentary biofilms- the challenge to microbial ecologists. Mar. Ecol. Prog. Ser. 112: 303-311.

Oliver J.D. 1982. Taxonomy scheme for the identification of marine bacteria. Deep Sea Res. 29: 795-798.

Promod K.C. \& K. Dhevendaran. 1987. Studies on phosphobacteria in Cochin backwater. J. Mar. Biol. Ass. India, 29: 297-305.

Rivkin R.B. \& M.R. Anderson. 1997. Inorganic nutrient limitation of oceanic bacterioplankton. Limnol. Oceanogr. 42: 730-740.

Seshadri S., S. Ignacimuthu \& C. Lakshminarsimhan. 2002. Variations in heterotrophic and phosphate solubilizing bacteria from Chennai, southeast coast of India. Indian J. Mar. Sci. 31: 69-72.

Thingstad T.F. \& F. Rassoulzadegan. 1995. Nutrient limitations, microbial food webs, and 'biological pumps': suggested interactions in a P- limited Mediterranean. Mar. Ecol. Prog. Ser. 117: 299-306.

Venkateswaran K. \& R Natarajan. 1983. Seasonal distribution of inorganic phosphate solubilizing bacteria and phosphatase producing bacteria in Porto Novo waters. Indian J. Mar. Sci. 12: 213-217. 
